Article

\title{
Factors Influencing the Frequency of Consumers' Purchases of Locally-Produced Rice in Indonesia: A Poisson Regression Analysis
}

\author{
Apri Wahyudi, John K. M. Kuwornu*(D), Endro Gunawan, Avishek Datta and Loc T. Nguyen \\ Department of Food, Agriculture and Bioresources, School of Environment, Resources and Development, \\ Asian Institute of Technology (AIT), Pathun Thani 12120, Thailand; apriyudi915@gmail.com (A.W.); \\ st119285@ait.asia (E.G.); datta@ait.asia (A.D.); locnguyen@ait.asia (L.T.N.) \\ * Correspondence: jkuwornu@ait.asia; Tel.: +66-624-309-104
}

Received: 20 May 2019; Accepted: 30 May 2019; Published: 4 June 2019

check for updates

\begin{abstract}
This study assessed the factors influencing the frequency of purchases of locally-produced rice using data collected from a sample of 400 consumers in Jakarta Province in Indonesia. The empirical results of a Poisson regression model revealed that socio-economic characteristics of the consumers (i.e., gender, age, occupation, education, and income), characteristics of the product (i.e., label and color), and the product's price and promotion significantly influenced consumers' frequency of purchasing locally-produced rice. The implication is that increasing the quality of locally-produced rice, applying an appropriate marketing strategy such as offering a relatively lower-priced product compared to the price of imported rice, and product promotion are necessary for increasing the frequency of consumers' purchases of locally-produced rice.
\end{abstract}

Keywords: agriculture; consumer preference; marketing mix; promotion; socio-economic factors

\section{Introduction}

The agricultural sector plays a strategic role in Indonesia's economy. Stakeholders in the agricultural sector have innovative and creative ideas for developing new products. However, a lack of market demand for locally-produced products has weakened this innovation. Consumers are often concerned about the quality and safety of locally-produced food [1]. The lack of consumer interest in purchasing local products is mainly due to their low quality, a low level of differentiation, market segmentation, and the development of specific client niches [2]. As a result, local products sold domestically are often of less quality compared to imported products.

Governments and businesses should work together to encourage societies to use local products. An integrated step is needed to persuade the community and related parties to prioritize local products. In Indonesia, the government has sought to regulate the use of local products such as through the Presidential Instruction No. 9 in 2009 [3]. Moreover, Decree No. Kep-08/M.Ekon/02/2009 by Indonesia's Coordinating Minister for Economic Affairs strengthened government policies to support the use of local products. The government action named "ACI (I Love Indonesian Products)" had a goal to improve the understanding, manufacture, and use of locally-produced products. In the long term, this action was expected to create jobs and increase domestic production.

Consumers' tendency to buy foreign products is something that local domestic industries must monitor in the context of the changing business environment, and they must adjust their marketing strategies accordingly [4]. The financial success of a company often relies on its marketing capability. Marketing is about identifying human and social needs. It is an art and science of identifying and accessing target markets, devising a set of strategies using the marketing mix elements, and keeping and growing consumers through establishing, conveying, and promoting consumers' value $[5,6]$. 
Consumer responses to a product need manufacturers' attention if they want to survive in the industry [7]. In a real-world shopping condition (including a food-service situation), the environment can directly affect consumers' emotions and their purchasing behaviors [8].

Indonesia's agricultural sector produces commodities that are distinct in terms of their quantity and quality. The agricultural commodities produced in Indonesia are variable in terms of appearance, water contents, duration of maturity and storage, size of the products, yields, and outputs. However, these differences challenge the competitiveness of the agricultural sector through the selection of products that can compete in the domestic and international markets. Locally-produced agricultural commodities have unique flavor and characteristics for which consumers are willing to pay a premium. Consumers buy local products due to their freshness and high quality. Moreover, culture and taste are an obvious reason for consumer preference for local products such as fruits and rice. Thus, consumers' food purchasing decisions are based on several cultural, psychological, and lifestyle factors, as well as food trends [9]. The preference to buy local food could be linked to attitudes, behaviors, and personality characteristics of the consumer [10]. Rice is a staple food for most Indonesians and an important component of national food security. Rice production increased at an annual average of $2.34 \%$ during 2010-2016 due to productivity improvements resulting from government programs such as direct seed and fertilizer support [11]. Given the importance of rice for Indonesia, the rice produced should meet the needs of consumers in terms of quality, quantity, and safety. Increased consumers' incomes lead to increased demand for quality. On the other hand, economic and demographic changes such as education, urbanization rates, and female labor force participation rates, along with current transportation and communications advances, influence consumer preferences. Consumers put more emphasis on the balance of quality, nutrition, and aesthetics, while the increased participation of female labor force, especially in urban areas, encourages consumers to choose food that is packed in such a way that they can easily be handled when shopping, easy to cook, and easy to prepare. The current rice marketing competition is very keen among rice marketing actors, including local rice producers, traders, and distributors of imported rice. To increase rice production, some superior rice varieties have been disseminated. The diversity of these varieties leads to the diversity of the nature and quality of the rice produced and sold in the market, and these enable the consumers to have diversity of choice of rice in the market [12]. Thus, this study is based on the theory of consumer behavior [13-16].

In society, there is a strong connection between food and culture, with food often being an integral part of culture [17]. Culture can influence consumer behavior, and the literature views food consumption as a complex interplay of cultural, economic, and social forces $[18,19]$. Moreover, there are many factors that influence consumer behavior and their frequency of purchases of certain foods, such as community and family structures, as well as other socio-economic factors [20]. The factors influencing consumers' considerations and their frequency of purchases of locally-produced products such as rice in Indonesia are not well understood. This is more important, as consumer preference for products is dynamic in the context of the government's drive to implement programs to increase the production of the locally produced agricultural commodities, including rice, for consumption by the population.

This is the gap in the existing literature that this study sought to fill. Therefore, this study analyzes the factors influencing consumers' frequencies of purchases of locally-produced rice in Jakarta Province, Indonesia. The rest of the manuscript is structured as follows: Section 2 presents the literature review, Section 3 presents the materials and methods; Section 4 presents the results and discussions, and Section 5 provides the conclusions.

\section{Literature Review}

\subsection{Overview of the Locally Produced Rice in Indonesia}

Rice is a staple food for most Indonesians and an important component of national food security. Table 1 shows that rice production increased at an annual average of 2.34\% during 2010-2016 due to 
productivity improvements resulting from government programs such as direct seed and fertilizer support $[11,21]$. Geographically, rice production is spread in various regions in Indonesia. The rice production centers are Java (53\%) and Sumatra (23\%). The rest of the regions are Sulawesi $(11 \%)$, Kalimantan (7\%), Nusa Tenggara (5\%), and eastern regions of Indonesia (Maluku and Papua) [21]. Several local rice varieties are being produced in Indonesia, including "pandan wangi," "setra ramos," and "rojolele." Rice consumption in Indonesia is increasing due to changing consumer behavior [21], and the increasing consumption resulted in a trade deficit during 2010-2016 (Table 2). Rice production costs in Indonesia are high due to the lack of new varieties and inadequate agricultural infrastructure, and this makes the price of locally produced rice relatively expensive compared to imported rice [22]. Generally, in Indonesia, the import of certain types of foods, including rice, was needed to maintain the availability of food and to stabilize food prices at affordable levels [23].

Table 1. Rice production and consumption in 2010-2016.

\begin{tabular}{ccc}
\hline Year & Production ('000 Ton) & Consumption ('000 Ton) \\
\hline 2010 & 40,239 & $40,238.79$ \\
2011 & 41,056 & 41,055 \\
2012 & 41,109 & 41,110 \\
2013 & 41,999 & 42,000 \\
2014 & 41,858 & 42,678 \\
2015 & 44,963 & 45,222 \\
2016 & 46,141 & 46,141 \\
\hline Rate (\%/year) & 2.34 & 2.32 \\
\hline
\end{tabular}

Table 2. Volume of rice export and import in 2010-2016.

\begin{tabular}{ccc}
\hline Year & Export (Ton) & Import (Ton) \\
\hline 2010 & - & 683,000 \\
2011 & 1000 & $2,745,000$ \\
2012 & 1000 & $1,787,000$ \\
2013 & 3000 & 471,000 \\
2014 & 2000 & 841,000 \\
2015 & 1000 & 860,000 \\
2016 & 1000 & 381,000 \\
\hline
\end{tabular}

Source: Indonesian Statistical Bureau, 2017 [11].

\subsection{Attributes of a Product}

A product can be defined as anything that is produced to be used, purchased, or consumed by manufacturers or producers as the fulfillment of consumer needs or desires. The combination of several attributes such as quality, features, brand name, package, label, and service of the goods that a company establishes and proposes to the target market to satisfy consumer needs can be defined as a product $[24,25]$.

Product quality is one of the attributes that have the capacity to satisfy consumers' desires [24]. The product has good quality because it is able to execute its function and meet consumer needs. In general, products are classified into four levels of quality: Poor, average, good, and excellent quality [26].

Product features can be defined as the way to differentiate one product from other products, characteristics of product design that can enable it to perform a specific task, and the most effective way to compete with other producers [24,27]. 
The product design is another way to attract consumers' attention and obtain more value for the product than other products. It indicates how a product is organized, produced, and appreciated by consumers $[24,26,27]$.

The brand of a product can be defined as a product's name, term, sign, symbol, or combination of those that recognize the producer's innovation. It includes the brand name, trademarks, and virtually all other means of product recognition. The product's brand name has implications for the producer to deliver a specific set of quality, features, and services to the consumer. An excellent brand conveys additional guarantees of assurance and can be used for promotional campaigns [24,28].

Packaging includes the covering of the product and can be used for promoting and increasing the value of the product [28]. It has two key functions: The technical function and the communication function. The technical function is that the package enables the product to be shipped, stored, and handled in a safe and reliable manner (transport capability, storage capability, and protection capability). The packaging allows the product to be easily used. Sometimes a package is reusable after the product is depleted/used. The communication function is that the package communicates a company's image through its design, label, colour, brand, and display.

Labels are part of a product that conveys information about the product from the seller. A label can identify the product or service and describe various things about the product or service such as the producer's name, location of the production, the content of the product or service, and the instructions for using the product or service [24].

\subsection{Locally-Produced Products and Consumer Preference}

The increasing preference for local food among consumers, social movements, the media, and academia is due to the solid conviction that it is more sustainable, safe, and healthy [29]. The definition of local product is rooted in geographic proximity [30]. There are two criteria usually used for geographical demarcation [31].

The first uses the distance between the location of production and the consumption (Peringer, 2008). The second criterion is related to political-administrative boundaries such as countries, states, or provinces [32]. These political-administrative boundaries may have a stronger impact than geographical boundaries on preferences for local products. Research revealed that Canadian consumers' preference for home-province beef versus beef labeled "local" depends on the geographic distance [33].

Consumer preference for a product or service can be defined as likes or dislikes for the product or service. This preference arises from the consumer's perception of the product and is measured by the usefulness of various quality of the products or services, as well as the ability of the product or service to satisfy the consumer's need [34-36]. a person can always create or rank the conditions of products or services from the most favored to the least favored. In a real shopping condition (including a food-service situation), the environment can directly affect a consumer's emotion and their purchase behavior [37]. Consumer preference is also influenced by beliefs, attitudes, psychological characteristics, social characteristics, and personal characteristics, as well as the marketing mix elements including the product, price, place, and promotion $[24,38,39]$.

\section{Material and Method}

\subsection{Study Area}

This study was undertaken in Jakarta Province in Indonesia. The province has a population of 10,277,628 and includes a considerable number of consumers of Indonesia's locally-produced agricultural commodities. Jakarta is the provincial and national capital city and is located at latitude $6^{\circ} 12^{\prime}$ South and longitude $106^{\circ} 48^{\prime}$ East. The province has an area of approximately $662.33 \mathrm{~km}^{2}$ (oceans: $6977.5 \mathrm{~km}^{2}$ ) [11]. Administratively, Jakarta Province is divided into five municipalities (i.e., North, South, East, West, and Central Jakarta Province) and one district administration (i.e., Kepulauan Seribu) (Figure 1). 


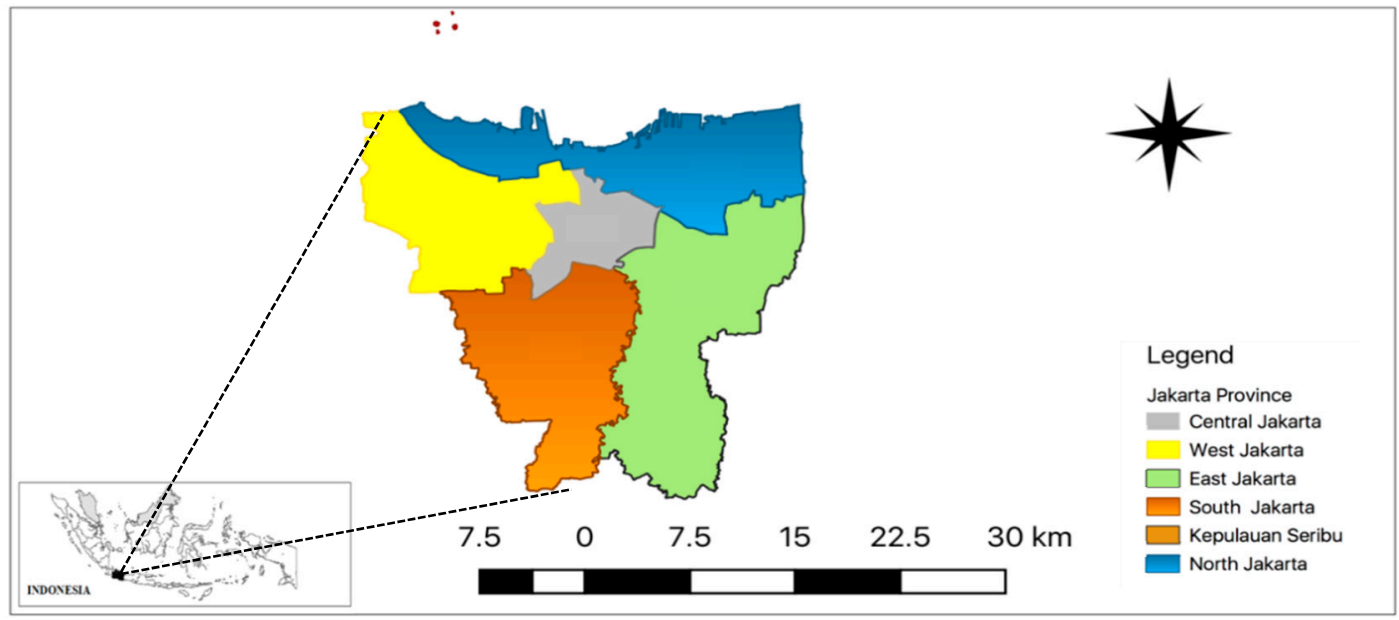

Figure 1. Map of Indonesia showing the location of Jakarta Province and its municipalities and district administration. Source: Indonesian Geospatial Information Agency [40].

The city of Jakarta is a lowland area with an average altitude of $+7 \mathrm{~m}$ above sea level. The total area of Jakarta, according to Governor Decree No. 171 of 2007, is $662.33 \mathrm{~km}^{2}$, with a sea area of $6977.5 \mathrm{~km}^{2}$. The population of Jakarta in 2017, based on projections of the 2010 Population Census population, was 10,374,235 inhabitants, with population growth rate of $0.94 \%$ per year, and the population density in 2017 was approximately 16 people $/ \mathrm{km}^{2}$. Jakarta Barat has the highest population density of approximately 20 people $/ \mathrm{km}^{2}$.

\subsection{Population, Sample Size Determination, Sampling Technique, and Data}

The total size of the study sample was determined using the following equation [41]:

$$
n=\frac{N}{\left(1+N e^{2}\right)}
$$

where $n$ denotes the sample size (respondents), $N$ denotes the total population, and $e$ denotes the margin of error, 0.05 ( $95 \%$ confidence level). This is a well-known approach to perform the power test for the sample used in the study. The power of the test is the chance to reject the null hypothesis, given that the null hypothesis is false (i.e., given that the alternative hypothesis is true). It is the process of determining the sample size for a study. Given the intended power, we can derive the required sample size, and, given the intended sample size, we can derive the resulting power. The equation determined that the appropriate sample size was $\sim 400$ respondents. The sub-sample sizes of consumers from each municipality are presented in Table 3.

Table 3. The sub-sample size per municipality of Jakarta Province.

\begin{tabular}{ccc}
\hline Municipality & Population of the Municipality & Sub-Sample Size per Municipality \\
\hline North Jakarta & $1,764,614$ & 69 \\
South Jakarta & $2,206,732$ & 86 \\
West Jakarta & $2,496,002$ & 97 \\
East Jakarta & $2,868,910$ & 112 \\
Central Jakarta & 917,754 & 36 \\
\hline Total & $10,254,012$ & 400 \\
\hline
\end{tabular}

Source: Indonesian Statistical Bureau [42].

A multistage sampling technique was used to select the consumers for data collection. First, a purposive sampling technique was employed to select five municipalities in Jakarta Province due to a high level of consumption of locally produced rice in the province. Second, proportional simple random sampling was employed to select the consumers in the five municipalities based on the 
population of each municipality (Table 3). The questionnaire for data collection was initially developed and pretested to remove all ambiguities before finalizing for the actual data collection. By this process, we ensured that quality data were obtained for the analysis.

\subsection{Method of Analysis}

This study used the Poisson regression model to assess the factors influencing the frequency of consumers' purchases of locally-produced rice. The Poisson regression model was selected because it is a suitable model for the estimation of count data [43-47]. The Poisson regression is an application of the Poisson distribution to a non-linear regression model [46,47]. This distribution relates independent variables $\left(x_{i}\right)$ to a scalar dependent variable $y$. The Poisson regression model is specified as follows:

$$
f\left(y / x_{i}\right)=\frac{e^{-\mu_{i}} \mu^{y}}{y !}
$$

Equation (3) can be specified as:

$$
\mu=\exp \left(\beta_{0}+\beta_{1} x_{1 i}+\beta_{2} x_{2 i}+\ldots+\beta_{k} x_{k i}\right),
$$

The Poisson regression model using the maximum likelihood estimation (MLE) was performed using EViews 8.

\subsection{Justification of the Variables Used for the Poisson Regression}

The variables that are hypothesized to influence the frequency of consumers' purchases of locally-produced rice were identified from the literature, a preliminary survey, and a focus group discussion of consumers in the province (Table 4). The positive and negative signs depict the hypothesized influence of each of the variables on the frequency of purchases of locally produced rice. The justifications of the variables are presented as follows:

Socio-economic characteristics of the respondents such as age, gender, education, income, and occupation were hypothesized to positively or negatively influence consumer preferences and their frequency of purchasing locally-produced rice. Several previous studies have stated the effects of socio-economic factors on purchases of locally-produced products. The factors, such as respondents' age, place of residence, and income, influenced their preference for local foods based on their knowledge, attitude, and perception [48]. Previous study revealed that age, education level, and the number of children in a family had significant positive influences on purchases of local foods in Canada, although attitudinally-based variables have far greater influence $[49,50]$. Demographic characteristics such as family size and dimension of fruit preferences, including country of origin, perceived quality, and environmental concerns, were important factors that influenced consumers' purchasing behavior towards locally grown or imported fruits [51]. According to the survey, the majority of the sample's female shoppers (54.7\%) buy locally-produced rice as compared to males (45.3\%). Moreover, approximately $53 \%$ of the females in the sample purchased locally-produced rice once a month, followed by $15.9 \%$ and $13.4 \%$ that purchased locally-produced rice twice a week and once a week, respectively. In addition, $11.6 \%$ and $1.3 \%$ of these females purchased locally-produced rice twice a month and every day in a week, respectively. Only $5.3 \%$ of the females in the sample never purchased locally-produced rice. 
Table 4. Descriptions of variables used for the Poisson regression, as well as their measurements and expected signs.

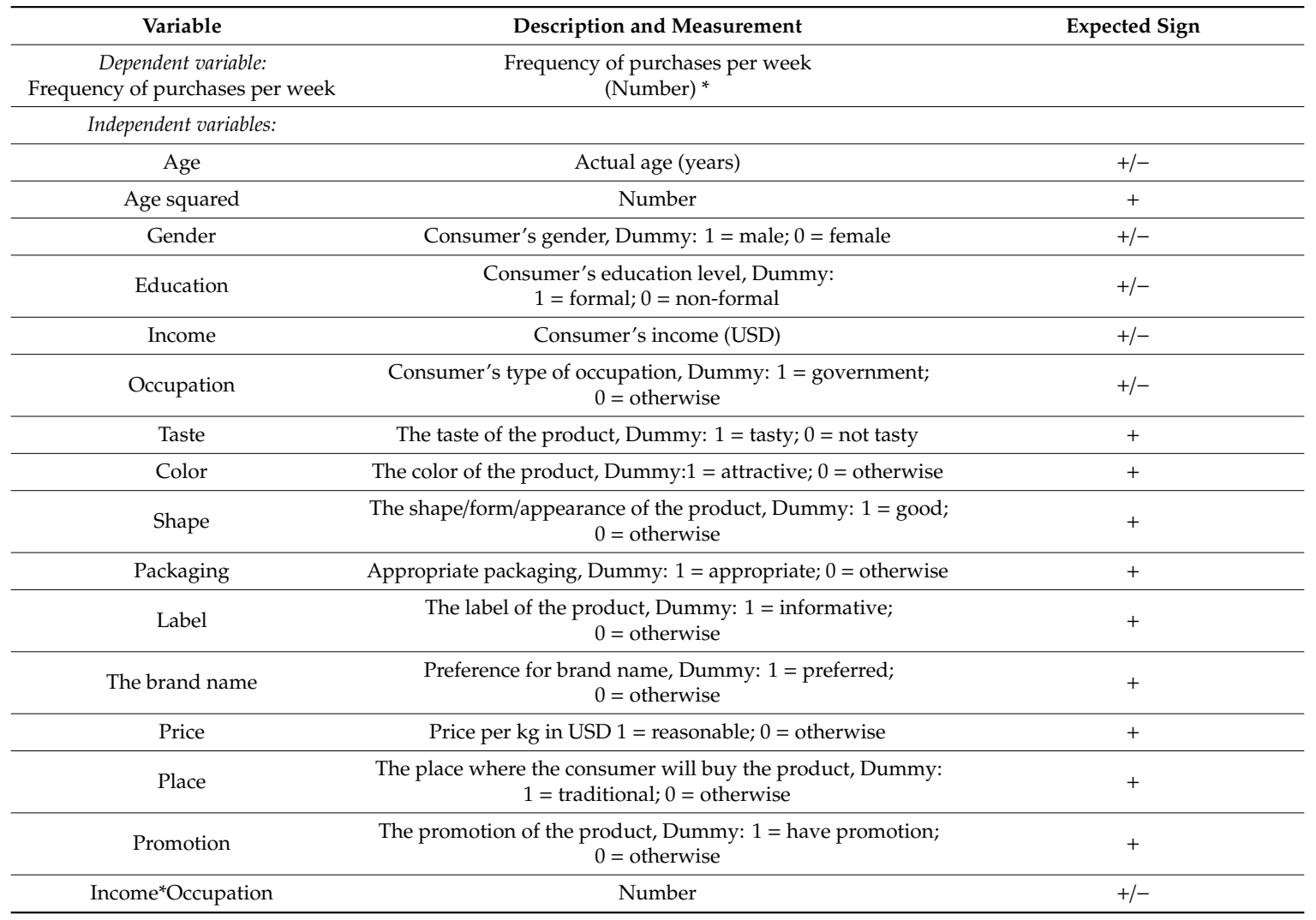

* The frequency of consumers' purchases of locally-produced rice was the number of times that consumers purchased locally-produced rice in a week. The respondents provided several responses to the frequency of purchases as follows: Once a week, twice a week, once per month, twice per month, and three times per month. The numbers were normalized to a per week basis and used for the Poisson regression.

Approximately $58 \%$ of the respondents had annual income lower than Rp. 50 million (US $\$ 1 \approx$ Rp. 13,200 ), and $14.7 \%$ of them purchased locally-produced rice twice per week. Moreover, $35 \%$ of the respondents had an annual income of Rp. 51 million-100 million, and 15.2\% of these respondents purchased locally-produced rice twice per week. In addition, $7.5 \%$ of the respondents had an annual income of above Rp. 101 million, and $29.2 \%$ of these respondents purchased locally-produced rice twice per week. This survey confirms the results of previous studies that found income to be influential for the consumption of local rice/food in Japan, Thailand, and Canada.

It is important to note that as age increases to a threshold, the consumer could be persuaded to purchase local rice due to customs and societal traditions. Therefore, we have included the square of their age to capture the nonlinear nature of the behavior of the consumers.

The taste, color, and shape (characteristics of quality) of rice were hypothesized to positively influence the frequency of purchases of locally produced rice $[10,49,52]$. These studies have revealed that delicious taste and appropriate appearance were the two primary attributes of high quality locally-produced rice. Moreover, the attractive appearance of local food is a factor known to influence consumers' purchases $[53,54]$. The combination of pleasant aroma and taste has been found to induce greater satiation, short-term satiety, and consumers' purchases of locally-produced food [55].

Packaging and labelling related to food safety are hypothesized to positively influence consumer preferences and their frequency of purchasing locally-produced rice. Food safety has been found to have a positive and significant influence on respondents' choice to purchase locally-produced rice [56]. Previous studies have shown that packaging is an important feature of the product to attract consumer attention $[57,58]$. Packaging can also inform consumers' evaluations of the quality and value of the product and thereby influences their choice of food items. Moreover, brand and labelling as 
non-sensory features have been found to influence consumer evaluations of product freshness $[59,60]$. The popularity of brands seems to influence consumers' perceptions of food products and may therefore facilitate healthy eating via social influence [61]. The majority of respondents $(43 \%)$ mentioned that they read the production and expiration dates on the label before purchasing the locally-produced rice. About $22 \%$ and $19 \%$ of these respondents read the content and the producer's name, respectively. This result is consistent with the previous study that labelling is seen as an indicator of food quality and safety, and it positively influences purchases of locally-produced rice. In addition, labelling as a non-sensory attribute influences consumers' evaluation of the freshness of the product.

The price, place (i.e., consumers' distance to the markets), and promotion (i.e., economic aspects) of a product are hypothesized to positively influence consumer preferences and their frequency of purchasing locally-produced rice. Several studies about food products indicated economic variables as significant factors in decisions about food consumption [62]. Price has been found to have an important impact on food purchases or consumption [63-67]. Research revealed that peoples' buying decisions can be influenced by easy access to markets [66]. Consumers believe that if they purchase a product near their residence, they will save more time and money [56]. Moreover, if there are long distances between the market and consumers' residences, they may not be able to access the market for their daily needs.

Other past studies have found that types of product or service promotion, including discounts and messages that appeal to consumers, can increase their preference [68-71]. Table 4 presents the descriptions, measurements, and expected signs of the variables used for the Poisson regression.

\subsection{Socio-Economic Characteristics of the Respondents}

The socio-economic characteristics of the respondents are presented in Table 5. Of the 400 respondents, 189 were males and 209 were females (the gender of two respondents could not be counted, as they did not respond to the question on gender). This is because the decision-makers regarding household consumption are mostly women, especially for decisions relating to basic food needs such as rice. Regarding the age of the respondents, $38.80 \%$ were between 21 and 30 years old, and $34.76 \%$ were between 31 and 40 years old. Approximately $42 \%$ of the respondents held a bachelor's degree.

Most $(\sim 70 \%)$ of the respondents were married. Regarding the respondents' occupation, $40 \%$ of the respondents worked in private companies, and approximately $42 \%$ worked as government officers. Approximately $48 \%$ of the respondents earned income in the range of Rp. 3,000,001-5,000,000 (US \$227.27-378.78), approximately 30\% earned more than Rp. 5,000,000 (US \$378.78), and approximately 23\% earned lower than 3,000,001 (US \$227.27), showing a broad distribution of income ranges of the respondents. This reflects the income distribution in Jakarta Province [11]. The exchange rate was US $\$ 1 \approx$ Rp. 14,000 at the time of data collection in December 2017. 
Table 5. Characteristics of the respondents.

\begin{tabular}{|c|c|c|c|c|}
\hline \multirow{2}{*}{ Categories } & \multicolumn{2}{|c|}{ Gender } & \multirow{2}{*}{ Total } & \multirow{2}{*}{$\%$} \\
\hline & Male & Female & & \\
\hline \multicolumn{5}{|l|}{ Age } \\
\hline Under 20 years & 2 & 3 & 5 & 1.26 \\
\hline 21-30 years & 69 & 85 & 154 & 38.80 \\
\hline $31-40$ years & 64 & 74 & 138 & 34.76 \\
\hline $41-50$ years & 29 & 30 & 59 & 14.86 \\
\hline $51-60$ years & 21 & 17 & 38 & 9.57 \\
\hline Above 60 years & 3 & - & 3 & 0.76 \\
\hline \multicolumn{5}{|l|}{ Educational Background } \\
\hline Non-formal & 1 & - & 1 & 0.25 \\
\hline Lower than bachelor's degree & 98 & 86 & 184 & 46.35 \\
\hline Bachelor's degree & 70 & 94 & 164 & 41.31 \\
\hline Higher than bachelor's degree & 19 & 29 & 48 & 12.09 \\
\hline \multicolumn{5}{|l|}{ Marital status } \\
\hline Single & 52 & 64 & 116 & 29.30 \\
\hline Married & 135 & 145 & 280 & 70.21 \\
\hline \multicolumn{5}{|l|}{ Occupation } \\
\hline Government officer & 71 & 82 & 153 & 39.23 \\
\hline Private company officer & 75 & 80 & 155 & 40 \\
\hline State enterprises officer & 8 & 4 & 12 & 3.08 \\
\hline Business owner & 10 & 12 & 22 & 5.64 \\
\hline Other & 17 & 31 & 48 & 12.31 \\
\hline \multicolumn{5}{|l|}{ Income per month (Rp.) } \\
\hline Below 500,000 & 4 & 6 & 10 & 2.58 \\
\hline $500,001-1,000,000$ & 8 & 5 & 13 & 3.36 \\
\hline $1,000,001-2,000,000$ & 13 & 4 & 17 & 4.40 \\
\hline $2,000,001-3,000,000$ & 22 & 26 & 48 & 12.40 \\
\hline $3,000,001-4,000,000$ & 61 & 59 & 120 & 31 \\
\hline $4,000,001-5,000,000$ & 23 & 40 & 63 & 16.28 \\
\hline Above $5,000,000$ & 55 & 61 & 116 & 29.97 \\
\hline
\end{tabular}

Source: Field survey, 2017.

\section{Results and Discussion}

\subsection{Characteristics and Varieties of Locally-Produced Rice in Jakarta Province, Indonesia}

Characteristics of the locally-produced rice that consumers purchase are shown in Figure 2. The survey results revealed that $25 \%$ of the respondents chose taste as the most important attribute that influenced their purchase of locally-produced rice, followed by price $(23 \%)$, color $(20 \%)$, appearance $(11 \%)$, packaging $(5 \%)$, labelling $(4 \%)$, and other characteristics such as the nutritional values and the variety $(11 \%)$. 


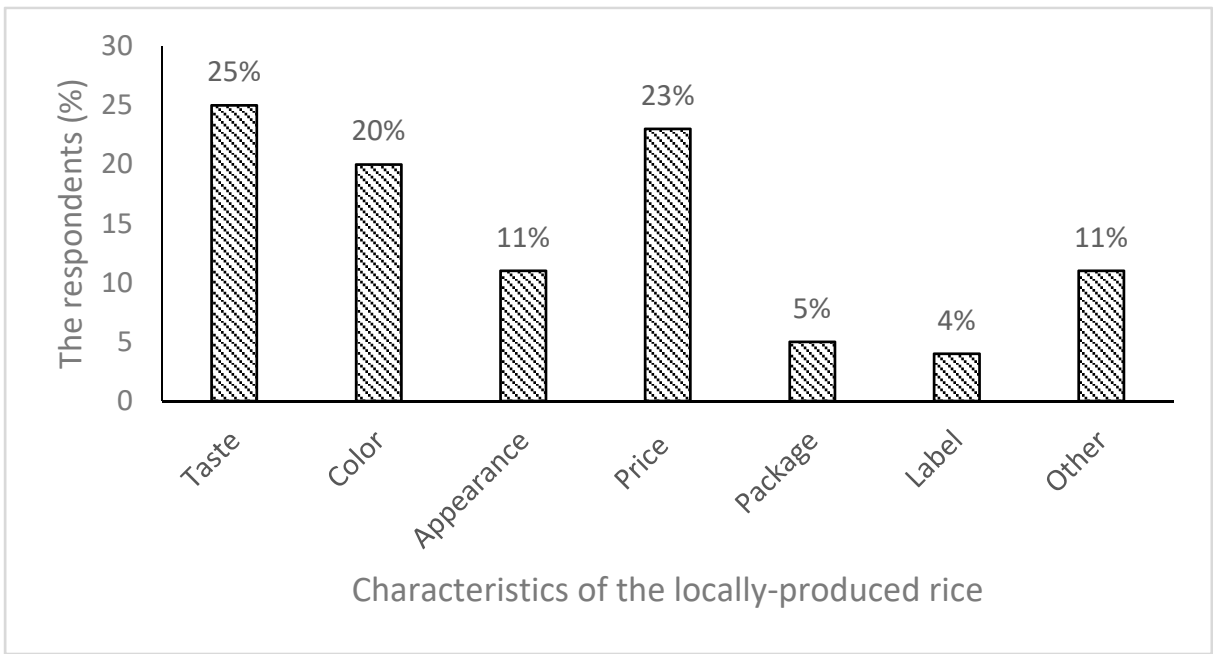

Figure 2. Characteristics of the locally-produced rice. Source: Field survey, 2017.

Most of the respondents (57.5\%) mentioned that it is easy to recognize the locally-produced rice, and $51.5 \%$ believed they could distinguish the locally-produced from imported rice. There are several ways the respondents can recognize the locally-produced rice, namely by the brand name $(38.5 \%)$, by touching $(26 \%)$, by visually observations $(22.33 \%)$, and through advertising $(11.2 \%)$, (Figure 3$)$.

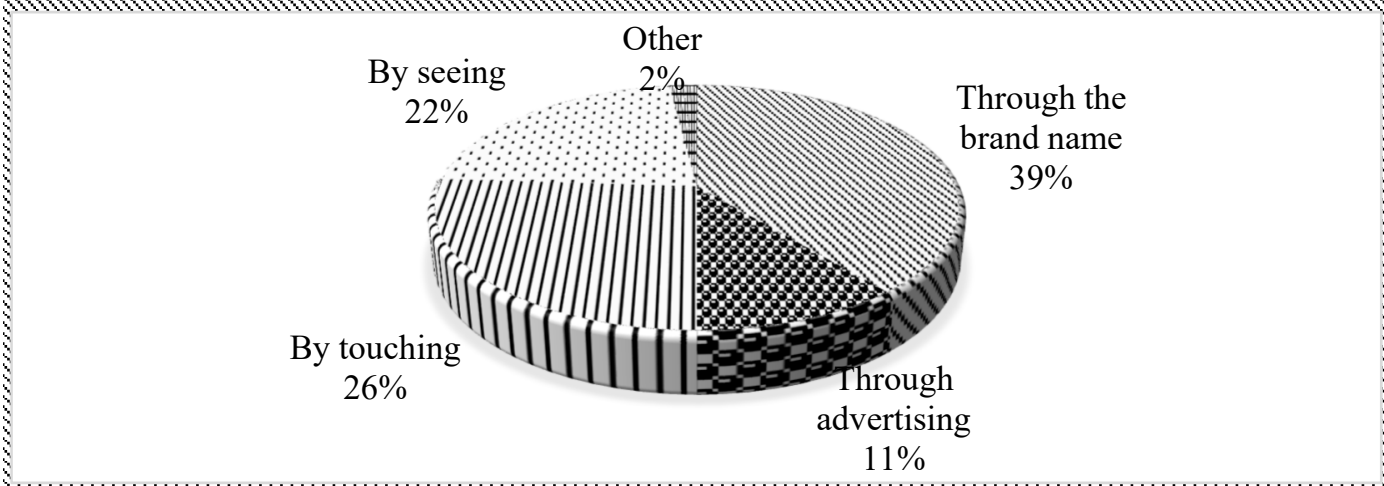

Figure 3. Means of recognizing the locally-produced rice. Source: Field survey, 2017.

Plain rice is the most common type of locally-produced rice purchased by consumers in Jakarta Province because it has a good taste, it is considered soft, and it is considered a bit sticky [72]. Though plain rice is not as healthy as brown rice, most of the surveyed consumers preferred it. Approximately $79 \%$ of the respondents preferred plain rice, followed by $14.5 \%$ who preferred brown rice, and $6.8 \%$ of the respondents who preferred other types of rice such as sticky rice. The respondents preferred locally-produced rice to the imported rice. Approximately $41 \%$ of the respondents preferred locally-produced because it is easy to find on the market, $35.8 \%$ preferred it because of the taste, and $23.2 \%$ had other reasons such as its reasonable price and promotion.

There were several varieties of locally-produced rice in the market in Jakarta Province. Many $(34 \%)$ of the respondents knew of the locally-produced rice known as pandan wangi, $23.7 \%$ knew of the rojolele variety, $19.6 \%$ knew of the beras merah (brown rice) variety, and $10.5 \%$ knew of the ciherang variety; $4.7 \%$ knew Inpari 12 (pera), 2.9\% knew mekongga as a locally produced rice, and $4.7 \%$ knew other varieties such as Inpari 13 as the locally produced rice (Figure 4). 


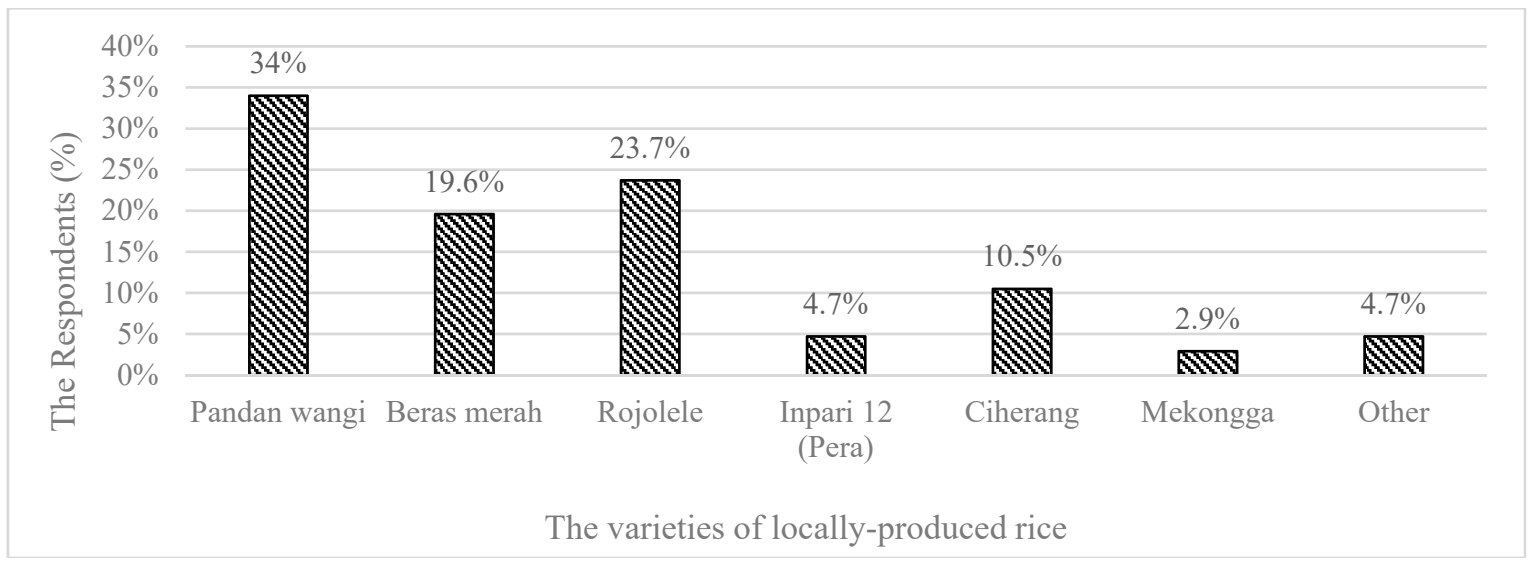

Figure 4. The locally-produced rice varieties in Jakarta Province, Indonesia. Source: Field survey, 2017.

The respondents were aware of the locally-produced rice through several means, including friends and/or family members (32.2\%), television (23.3\%), internet or social media $(21.6 \%)$, newspapers $(11 \%)$, and magazines (6.9\%), (Figure 5).

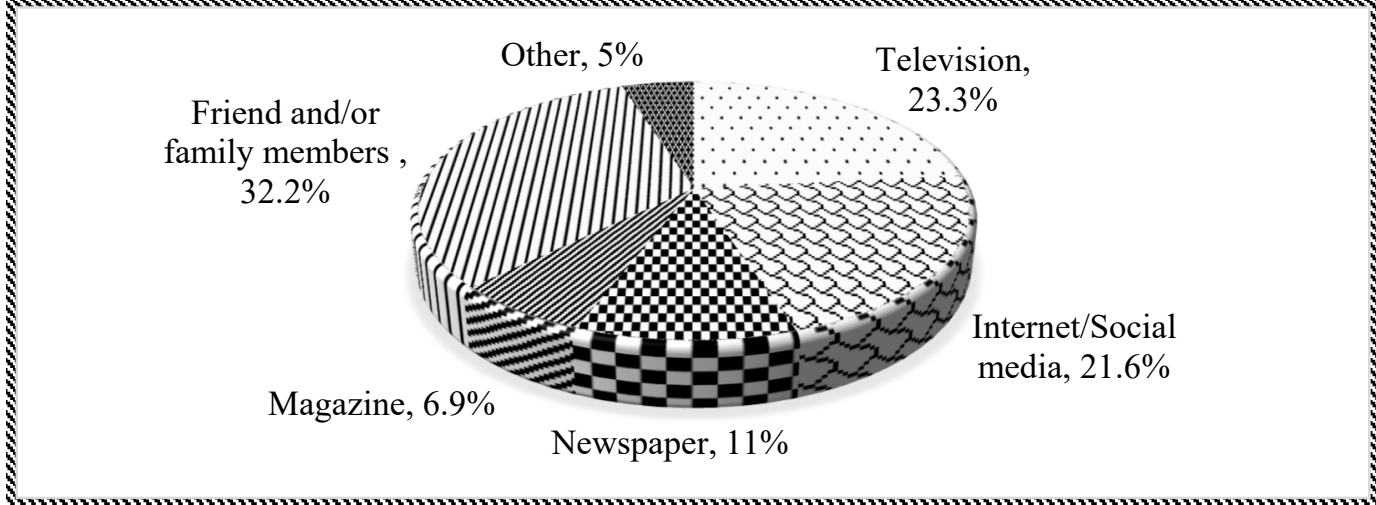

Figure 5. The source of information about the locally-produced rice. Source: Field survey, 2017.

\subsection{Factors Influencing the Frequency of Consumers' Purchases of Locally-Produced Rice}

Table 6 presents the results of the Poisson regression model. Eight of the fourteen independent variables used had a significant influence on the frequency of consumers' purchases of locally-produced rice. The R-squared of 0.075 indicates that approximately $8 \%$ of the variations in the frequency of purchases of locally produced rice is influenced by the independent variables. Though the R-squared value is considerably small, this is typical of cross-sectional data. Nevertheless, the average log likelihood statistic of $-4.48(p<0.01)$ suggests that the model fits the data and that the independent variables jointly influence the frequency of consumers' purchases of the locally-produced rice. 
Table 6. Results of the Poisson regression of consumers' frequency of purchases of locally-produced rice $(\mathrm{n}=320)$

\begin{tabular}{cccc}
\hline Variables & Coefficient & Std. error & $p$-Value \\
\hline Constant & 4.456 & 0.259 & 0.000 \\
Gender & $0.076^{*}$ & 0.039 & 0.051 \\
Age & $-0.113^{* * *}$ & 0.014 & 0.000 \\
Square of the Age & $0.001^{* *}$ & 0.000 & 0.000 \\
Education & $-0.014^{*}$ & 0.008 & 0.070 \\
Occupation & 0.051 & 0.076 & 0.499 \\
Income & $0.222^{* *}$ & 0.090 & 0.013 \\
Taste & -0.048 & 0.065 & 0.458 \\
Color & $-0.220^{* * *}$ & 0.054 & 0.000 \\
Appearance & 0.020 & 0.044 & 0.648 \\
Package & -0.044 & 0.048 & 0.368 \\
Label & $0.095^{*}$ & 0.050 & 0.061 \\
The brand name & -0.001 & 0.052 & 0.979 \\
Price & $1964.810^{* *}$ & 775.656 & 0.011 \\
Place & 0.038 & 0.047 & 0.423 \\
Promotion & $0.074^{*}$ & 0.045 & 0.099 \\
Income*occupation & $1.40 \times 10^{-5}$ & $1.38 \times 10^{-5}$ & 0.312 \\
\hline & Regression Diagnostics & \\
R-squared & 0.074727 & Mean dependent var & 8.965625 \\
Adjusted R-squared & 0.025867 & S.D. dependent var & 8.885306 \\
Avg. log likelihood & -4.481019 & Prob(LR statistic) & 0.000000 \\
\hline
\end{tabular}

$* * *, * *, *$ denote significance at $1 \%, 5 \%$ and $10 \%$ levels, respectively.

Consumers' gender, square of the age, occupation, income, as well as the label and price of the locally-produced rice had a positive significant influence on the frequency of their purchases of locally-produced rice. On the other hand, consumers' age, education, and the color of the locally-produced rice had a negative significant influence on the frequency of consumers' purchases of locally-produced rice.

The presentations of the descriptive statistics were based on the total sample size of 400 . However, the analysis of the frequency of purchases (Poisson regression) was based on the sample size of 320 due to some missing information identified during the cleaning of the data. Nevertheless, following [41], the margin of error of the sample based on this sample size is $5.6 \%$. This implies that we are $94.4 \%$ confident in the results based on this sample and that the results can be generalized to the population of the consumers of locally-produced rice in Jakarta Province in Indonesia.

Gender had positive significant influence on the frequency of consumers' purchases of locally-produced rice $(p<0.1)$. This means that the males purchased the locally-produced rice more frequently than the females. In general, Indonesian women do the shopping and prepare food for the family [28]. This result suggests that even though the women are more involved in shopping for the family, they have less preference for locally produced as compared to the males.

Similarly, consumers' annual income had a positive significant influence on the frequency of purchases of locally-produced rice $(p<0.05)$. Income is directly related to purchasing power. The personal income of consumers influences their buying ability because it determines the level of purchases of products and services [53].

The labelling of the locally-produced rice had a positive significant influence on the frequency of consumers' purchases of locally-produced rice $(p<0.1)$. The rice labels carried a great deal of information. For the locally produced rice, the label was necessary to provide information about the quality of the rice such as the name of the variety, the production date, and the expiration date $[56,59,60]$.

The price variable had a positive significant influence on the frequency of consumers' purchases of locally-produced rice $(p<0.05)$. Consumers spend to maximize satisfaction or utility, and rice is a staple food and basic need for most of the Indonesian population. The reasonable price of locally-produced rice was one of the factors that influenced its purchase. It is worthy to note that the reasonable price 
depends on the consumer's purchasing power, which, in turn, depends on the income level. This result is consistent with previous studies that found that economic factors such as price influence purchases of products [63-67].

Consumer's education had a negative significant influence on the frequency of their purchases of locally-produced rice $(p<0.1)$. Consumers whose educational levels were lower than a bachelor's degree were less likely to buy locally-produced rice. Approximately $52 \%$ of the respondents with an education level lower than a bachelor's degree purchased locally-produced rice once a month, compared with $55 \%$ of the respondents that had an education level higher than a bachelor's degree. Previous studies revealed that respondents with education levels lower than high school or a bachelor's degree are less likely to purchase local food, as they may have adequate information on alternative products that may appear to be of superior quality compared to the local food products $[10,49]$.

The color variable had a negative significant influence on the frequency of consumers' purchases of locally-produced rice $(p<0.01)$. Approximately $51 \%$ of the respondents purchased locally-produced rice once a month because the color was attractive. Approximately $58 \%$ of the respondents did not pay attention to the color of the locally-produced rice. This finding contrasts with previous studies that found color to be one of the main features indicating the high quality of local rice [10,49,52].

Age had a negative significant influence on the frequency of consumers' purchases of locally-produced rice $(p<0.01)$. This implies that increases in consumers' age decreases the frequency of purchases of locally-produced rice. Approximately $48 \%$ of the respondents who were 20-30 years of age purchased locally-produced rice once a month. Moreover, $53.7 \%$ and $56.6 \%$ of the respondents who were 31-40 and 41-50 years of age, respectively, purchased locally-produced rice once a month. Next, $60 \%$ of the respondents were more than 51 years, and they also purchased locally-produced rice once a month. This result is consistent with the previous studies that age had a significant effect on consumers' preferences for local food $[10,49,50]$. Nevertheless, as age increases up to a point, the effect becomes significantly positive $(p<0.01)$, although negligible, on consumers' preference for locally-produced rice. This may be because the aged could be persuaded to purchase local rice due to customs and societal traditions.

The promotion variable had a positive significant influence on consumers' frequency of purchases of locally-produced rice $(p<0.1)$. This result suggests that effective promotion of locally-produced rice increased consumers' frequency of purchase. Approximately $51 \%$ of the respondents purchased the locally-produced rice once a month due to promotion. In addition, $16.7 \%$ of the respondents purchased the locally-produced rice twice a week due to promotion. This result is in line with previous studies that found that a combination of discounts and other forms of promotion including online programs can influence the consumers' motivation to purchase a product, thereby increasing producers' profits [51,70].

Finally, we expected the interaction effect of income and occupation to influence the frequency of purchases. However, this variable was not significant.

\section{Conclusions}

Locally-produced products are important for improving the economic condition of local inhabitants, as these inhabitants produce for consumption and market the surplus for income to sustain their livelihoods. This study described the characteristics of locally-produced rice in Jakarta Province in Indonesia and analysed the factors influencing the frequency of consumers' purchases of this rice. The study is relevant for producers because the results can assist in the preparation of marketing strategies. Moreover, producers can develop promotional strategies, especially appropriate advertisements based on the needs and desires of consumers.

Several varieties of locally-produced rice are known by consumers in Jakarta Province. Pandan wangi is the most common variety, followed by rojolele, beras merah (brown rice), inpari 12 (pera), ciherang, and mekongga. The characteristics of the locally-produced rice such as its smell, 
texture, shape or form, color, and accessibility were the main factors that determined the consumers' preference for them.

The results of the Poisson regression revealed that gender, the square of the age of the respondent, occupation, annual income, promotion, label, and price had a positive significant influence on the frequency of consumers' purchases of locally-produced rice. However, age, education, and color had a negative significant influence on the frequency of consumers' purchases of locally-produced rice.

The results imply that the consumers considered price to be the most important factor influencing the frequency of purchases of locally-produced rice. Other factors such as label, color, and promotion also influenced the consumers' frequency of purchases of the locally-produced rice. Thus, increasing the quality of locally-produced rice, improving the labeling, and offering affordable price compared to the price of imported rice would increase the frequency of consumer purchases of locally-produced rice. The study provides the following recommendations. First, it is imperative that the government provide training and capacity-building support related to production practices to enable the farmers to produce quality rice. Second, the government should provide input subsidies for the farmers to enable them to reduce the price of the locally-produced rice in the market and thereby help to persuade more consumers to purchase it.

The promotion of locally-produced agricultural products is not only critical for the development of the agricultural sectors in developing and emerging economies like Indonesia that depend heavily on agriculture but is also imperative to improve the livelihood of the farming households.

This study is not without limitations. It is based only on data from Jakarta Province, which may not be representative of the entire population of Indonesia. Therefore, extending this study to other regions of the country to provide a broader perspective of consumers' preferences for locally-produced rice would be an excellent opportunity for future research. Indonesia is a developing country that has several cities and provinces with different socio-economic characteristics of their consumers. Extending the study to these other cities would improve our understanding of consumer preferences that would provide directions for the formulation and implementation of appropriate and effective marketing strategies for locally-produced rice. Moreover, other variables such as product safety that would reflect health and environmental issues should also be considered in any future studies.

In addition, the datum collected on varieties was a general one about the consumers' awareness of those varieties. We did not collect data on the consumers' preference for individual locally produced varieties. This is another excellent suggestion for future research. Further, the sign of the coefficient of the color variable did not meet our a priori expectation, and this would be re-examined in our future research. The agricultural commodities produced in Indonesia are variable in the terms of appearance, water contents, duration of maturity and storage, and the size of the products, yields, and outputs. The exact differences in all these attributes compared to imported rice would require laboratory analysis, which is beyond the scope of this study. This is also an excellent opportunity for future research. Similarly, an investigation into consumers' desirable colour and shape of the rice is another opportunity for future research. In addition, consumer preference based on water content in the rice would require laboratory analysis, and this presents another opportunity for future research. The differences in taste and how taste influences consumer preference is another excellent opportunity for future research. Finally, examining the differences in duration of maturity and storage, size of products, yields, and outputs is another opportunity for future research.

Author Contributions: A.W., J.K.M.K., E.G., A.D., and L.T.N. designed the research. A.W. collected the data. J.K.M.K. and A.W. analyzed the data. A.W., J.K.M.K., and E.G. drafted the manuscript. J.K.M.K., A.W., A.D., L.T.N., and E.G. worked on the flow, clarity, organizational structure, discussions, conclusions, and reviewed and revised the manuscript. J.K.M.K. served as the corresponding author.

Acknowledgments: The authors gratefully thank the Indonesian Agency for Agricultural Research and Development, and the Indonesian Ministry of Agriculture for providing financial support for this study. We also acknowledge our sincere gratitude to the consumers in the five Jakarta provinces for their patience, time and the information provided during the field survey.

Conflicts of Interest: The authors declare that there is no conflict of interest regarding the publication of this article. 


\section{References}

1. Camhuri, N.; Batt, P.J. Consumer perception of food quality in Malaysia. Br. Food J. 2015, 117, $1168-1187$. [CrossRef]

2. Lundy, M.; Gottret, V.M.; Cifuentes, W.; Ostertag, F.C.; Best, R.; Peters, D.; Ferris, S. Increasing the Competitiveness of Market Chains for Smallholder Producers; CIAT: Cali, Colombia, 2004.

3. Listrik Indonesia. Upaya Panjang Cinta Produk Lokal (In Bahasa); Listrik Indonesia: Jakarta, Indonesia, 2013; Available online: http://listrikindonesia.com/upaya_panjang_cinta_produk_lokal_514.htm (accessed on 17 October 2013).

4. Setiawan, E. Analisis sikap konsumen terhadap produk fashion lokal dan impor. J. Econ. 2014, 10, 38-47. (In Bahasa)

5. Kotler, P.T.; Keller, L.K. Marketing Management, 15th ed.; Pearson Education: New York, NY, USA, 2016.

6. Kotler, P.T.; Amstrong, G. Principles of Marketing, 14th ed.; Pearson Education: New York, NY, USA, 2012.

7. Budiman, J.A. Analisis Preferensi Konsumen Terhadap Keputusan Pembelian Madu di Kota Blitar. Ph.D. Thesis, Brawijaya University, Malang, Indonesia, 2014.

8. Campbell, J.M. Muy local: Differentiating hispamic and caucasian shoppers of locally produced foods in US grocery. J. Retail. Consum. Serv. 2013, 20, 325-333. [CrossRef]

9. Asp, E. Factors affecting food decisions made by individual consumers. Food Policy 1999, 24, $287-294$. [CrossRef]

10. Mirosa, M.; Lawson, R. Revealing the lifestyles of local food consumers. Br. Food J. 2012, 114, 816-825. [CrossRef]

11. Statistical Bureau. Statistical Yearbook of Indonesia; Government of Indonesia: Jakarta, Indonesia, 2017.

12. Ambarinanti, M. Analisis Faktor-Faktor Yang Dapat Mempengaruhi Produksi dan Ekspor Beras Indonesia; Institut Pertanian Bogor: Bogor, Indonesia, 2007. (In Bahasa)

13. Fishbein, M.; Ajzen, I. Belief, Attitude, Intention, and Behavior: An Introduction to Theory and Research; Addison-Wesley: Boston, MA, USA, 1975.

14. Ajzen, I.; Fishbein, M. Understanding Attitudes and Predicting Social Behavior; Prentice-Hall Inc.: Englewood Cliffs, NJ, USA; Reading, MA, USA, 1980.

15. Ajzen, I. From intentions to actions: a theory of planned behavior. In Action Control: From Cognition to Behavior; Kuhl, J., Beckmann, J., Eds.; Springer: Berlin/Heidelberg, Germany; New York, NY, USA, 1985; pp. 11-39.

16. Ajzen, I. The theory of planned behavior. Organ. Behav. Hum. Decis. Process. 1991, 50, 179-211. [CrossRef]

17. Bhugra, D.; Bhui, K.; Mallett, R.; Desai, M.; Jayshree, S.; Leff, J. Cultural identity and its measurement: a questionnaire for Asians. Int. Rev. Psychiatry 2009, 11, 244-250.

18. Franchi, M. Food choice: Beyond the chemical content. Int. J. Food Sci. Nutr. 2012, 63, 17-28. [CrossRef]

19. Lang, M.; Stanton, J.; Qu, Y. Consumers' evolving definition and expectations for local food. Br. Food J. 2014, 116, 1808-1820. [CrossRef]

20. Anic, I.D.; Rajh, S.P.; Rajh, E. Antecedents of food-related consumer decision-making styles. Br. Food J. 2014, 116, 431-450. [CrossRef]

21. National Development Planning Agency_Bappenas Report; Government of Indonesia: Jakarta, Indonesia, 2014. Available online: http://www.bappenas.go.id/ (accessed on 24 April 2018).

22. Komalasari, T.D. Impor Beras Masih Tinggi (in Bahasa); Pikiran Rakyat: Bandung, Indonesia, 2017; Available online: http://www.pikiran-rakyat.com/ekonomi/2017/07/10/impor-beras-masih-tinggi-404884 (accessed on 23 August 2017).

23. Indonesia's National Government Internal Auditor-BPKP; Government of Indonesia: Jakarta, Indonesia, 2015. Available online: https://www.kemenkeu.go.id/en/publications/news/the-ministry-of-pdtt-created-acollaborative-monitoring-system/ (accessed on 30 May 2018).

24. Kotler, P.; Amstrong, G. Principles of Marketing, 13th ed.; Pearson Education: New York, NY, USA, 2009.

25. Akpoyomare, O.B.; Adeosun, L.P.K.; Rahim, A.G. The influence of product attributes on consumer preference decision in the Nigerian food and beverage industry: a study of Lagos Metropolis. Am. J. Bus. Manag. 2012, 1, 196-201.

26. Kotler, P.; Armstrong, G. Principles of Marketing, 12nd ed.; Pearson Education: New York, NY, USA, 2008.

27. Pride, W.M.; Ferrel, O.C. Marketing, 17th ed.; Cengage Learning: South-Western, AZ, USA, 2014.

28. Perreault, W.D.; Cannon, J.P.; McCarthy, E.J. Essentials of Marketing, 12th ed.; Mac-Graw Hill Inc.: New York, NY, USA, 2010.

29. Adams, D.C.; Salois, M.J. Local versus organic: a turn in consumer preferences and willingness-to-pay. Renew. Agric. Food Syst. 2010, 25, 331-341. [CrossRef] 
30. Thompson, E., Jr.; Harper, A.M.; Kraus, S. Think Globally-Eat locally: San Fransisco Foodshed Assessment. 2008. Available online: http://www.farmland.org/programs/states/ca/Features\%20Stories/San-FransiscoFoodshed-Report.asp (accessed on 5 September 2017).

31. Fernández-Ferrína, P.; Calvo-Turrientesb, A.; Bandec, B.; Miren Artaraz-Miñóna, M.; Galán-Laderod, M.M. The valuation and purchase of food products that combine local, regional and traditional features: The influence of consumer ethnocentrism. Food Qual. Prefer. 2108, 64, 138-147. [CrossRef]

32. Darby, K.; Batte, M.; Ernst, S.C.; Roe, B. Willingness to pay for locally produced foods: a customer intercept study of direct market and grocery store shoppers. In Proceedings of the Annual meeting of the American Agricultural Economics Association, Long Beach, CA, USA, 23-26 July 2006.

33. Lim, K.H.; Hu, W. How Local Is Local? a Reflection on Canadian Local Food Labeling Policy from Consumer Preference. Can. J. Agric. Econ. 2017, 64, 71-88. [CrossRef]

34. Munandar, J.M.; Udin, F.; Amelia, M. Analisis faktor yang mempengaruhi preferensi konsumen produk air minum dalam kemasan di Bogor. J. Teknol. Ind. Pertan. IPB 2012, 13, 97-107. (In Bahasa)

35. Guleria, D.; Parmar, Y.S. a study of consumer preference for smartphone: a case of Solan town of Himachal Pradesh. Int. J. Mang. Res. Rev. 2015, 5, 193-200.

36. Marwan, A. Marketing, 2nd ed.; BPFE Universitas Gadjah Mada: Yogyakarta, Indonesia, 1990. (In Bahasa)

37. Campbell, J.; DiPietro, R.B.; Remar, D. Local foods in a University setting; price/quality inference and customer's willingness to pay. Int. J. Hosp. Manag. 2014, 42, 39-49. [CrossRef]

38. Tjiptono, F. Strategi Pemasaran, 3rd ed.; Andi: Yogyakarta, Indonesia, 2008. (In Bahasa)

39. Tunggal, A.W. Tanya-Jawab: Perilaku Konsumen dan Pemasaran Strategi; Harvarindo: Jakarta, Indonesia, 2005. (In Bahasa)

40. Indonesian Geospatial Information Agency. Atlas Administrasi DKI Jakarta; BIG: Bogor, Indonesia. Available online: http://www.big.go.id/atlas-administrasi/ (accessed on 10 March 2019).

41. Yamane, T. Statistics, An Introductory Analysis, 2nd ed.; Harper and Row: New York, NY, USA, 1967.

42. Indonesian Statistical Bureau. Indonesian Statistic 2015; BPS: Jakarta, Indonesia, 2016.

43. Greene, W.H. FIML Estimation of Sample Selection Models for Count Data; Working Papers 97-02; Department of Economics, Leonard N Stern School of Business, New York University: New York, NY, USA, 1997.

44. Greene, W.H. Econometric Analysis, 4th ed.; Prentice Hall: New Jersey, NJ, USA, 2000.

45. Ferrara, O.; Ward, R.W. Evidence of Changes in Preferences among Beef Cuts Varieties: An Application of Poisson Regressions. Presented at the American Agricultural Economics Association Annual Meetings, Portland, OR, USA, 29 July-1 August 2007; 2007.

46. Mensah-Bonsu, A.; Sarpong, D.B.; Al-Hassan, R.; Asuming-Brempong, S.; Egyir, I.S.; Kuwornu, J.K.M.; Osei-Asare, Y.B. Technology Adoption and Land and Water Management Practices among Maize Farmers in Ghana. In Proceedings of the International Conference of Agricultural Production, "Increasing Agricultural Productivity and Enhancing Food Security in Africa: New Challenges and Opportunities", Addis Ababa, Ethiopia, 1-3 November 2011.

47. Mensah-Bonsu, A.; Sarpong, D.B.; Al-Hassan, R.; Asuming-Brempong, S.; Egyir, I.S.; Kuwornu, J.K.M.; Osei-Asare, Y.B. Intensity of and factors affecting land and water management practices among smallholder maize farmers in Ghana. Afr. J. Agric. Resour. Econ. 2017, 12, 142-157.

48. Latiff, Z.A.A.; Ayob, M.A. Preference of consumer toward imported rice and local rice in Kelantan. Int. J. Community Dev. Manag. Stud. 2017, 1, 73-83.

49. Cranfield, J.; Henson, S.; Blandon, J. The effect of attitudinal and socio-demographic factors on the likelihood of buying locally-produced food. Agribusiness 2012, 28, 205-221. [CrossRef]

50. Bianchi, C. Exploring urban consumers' attitudes and intentions to purchase local food in Chile. J. Food. Prod. Market. 2017, 23, 553-569. [CrossRef]

51. Terano, R.; Mohamad, Z.; Rezai, G.; Hanum, Z. Preference for locally grown or imported fruit among the millennial generation in Johor, Malaysia. J. Food. Prod. Mark. 2016, 22, 891-904. [CrossRef]

52. Zepeda, L.; Nie, C. What are the odds of being an organic or local food shopper? Multivariate analysis of US food shopper lifestyle segments. Agric. Hum. Values 2012, 29, 467-480. [CrossRef]

53. Megicks, P.; Memery, J.; Angell, R.J. Understanding local food shopping: Unpacking the ethical dimension. J. Mark. Mang. 2012, 28, 264-289. [CrossRef]

54. Nederkoorn, C.; Houben, K.; Havrmans, C. Taste the texture: The relation between subjective tactile sensitivity, mouthfeel and picky eating in young adults. Appetite 2019, 136, 58-61. [CrossRef] [PubMed] 
55. Yin, W.; Hewson, L.; Linforth, R.; Taylor, M.; Fisk, I.D. Effects of aroma and taste, independently or in combination, on appetite sensation and subsequent food intake. Appetite 2017, 114, 265-274. [CrossRef] [PubMed]

56. Rahnama, H. Consumer motivations toward buying local rice: The case of Northern Iranian consumers. Appetite 2017, 114, 350-359. [CrossRef]

57. Silayoi, P.; Speece, M. The importance of packaging attributes: a conjoint analysis approach. Eur. J. Mark. 2007, 41, 1495-1517. [CrossRef]

58. Karimi, P.; Mahdieh, O.; Rahmani, M. The study of relationship between packaging elements and purchase behavior: Consumers of food, cosmetics, and health products. Interdiscip. J. Contemp. Res. Bus. 2013, 5, 281-295.

59. Carlucci, D.; Nocella, G.; De Devitiis, B.; Viscecchia, R.; Bimbo, F.; Nardone, G. Consumer purchasing behavior towards fish and seafood products. Patterns and insights from a sample of international studies. Appetite 2015, 84, 212-227. [CrossRef] [PubMed]

60. Zhang, T.; Lusk, K.; Mirosa, M.; Oey, I. Understanding young immigrant Chinese consumers' freshness perceptions of orange juices: a study based on concept evaluation. Food Qual. Prefer. 2016, 48, 156-165. [CrossRef]

61. Koening, L.M.; Giese, H.; Stok, F.M.; Renner, B. The social image of food: Associations between popularity and eating behaviour. Appetite 2017, 114, 248-258. [CrossRef] [PubMed]

62. Powell, L.M.; Han, E.; Chaloupka, F.J. Economic contextual factors, food consumption, and obesity among U.S. Adolescents. J. Nutr. 2010, 140, 1175-1180. [CrossRef] [PubMed]

63. Arsil, P.; Li, E.; Bruwer, J. Perspectives on consumer perceptions of local foods: a view from Indonesia. J. Int. Food Agribus. Mark. 2014, 26, 107-124. [CrossRef]

64. Garg, T.; Barrett, C.B.; Gomez, M.I.; Lentz, E.C.; Violette, W.J. Market prices and food aid local and regional procurement and distribution: a multi-country analysis. World Dev. 2013, 49, 19-29. [CrossRef]

65. Kang, S.; Rajagopal, L. Perceptions of benefits and challenges of purchasing local foods among hotel industry decision makers. J. Foodserv. Bus. Res. 2014, 17, 301-322. [CrossRef]

66. Knight, A.J. Evaluating local food programs: The case of select Nova Scotia. Eval. Program Plan. 2013, 36, $29-39$. [CrossRef]

67. Rahnama, H.; Rajabpour, S. Factors for consumer choice of dairy products in Iran. Appetite 2017, 111, 46-55. [CrossRef]

68. Cucchiara, C.; Kwon, S.; Ha, S. Message framing and consumer responses to organic seafood labeling. Br. Food J. 2015, 17, 1547-1563. [CrossRef]

69. Vecchio, R.; Lombardi, A.; Cembalo, L.; Caracciolo, F.; Cicia, G.; Masucci, F.; Di Francia, A. Consumers' willingness to pay and drivers of motivation to consume omega-3 enriched mozzarella cheese. Br. Food J. 2016, 118, 2404-2419. [CrossRef]

70. Gomez, M.; Rao, V.R. Market power and trade promotions in US supermarkets. Br. Food J. 2009, 111, 866-877. [CrossRef]

71. Tang, Y.C.; Wang, Y.M.; Huang, J.Y. Optimal promotional strategy for intra-category cross-selling: An application to culinary products in Taiwan. Br. Food J. 2014, 116, 80-90. [CrossRef]

72. Indrasari, S.D.; Purwaningsih, P.; Apriyati, E.; Ardhiyanti, S.D. Preferensi konsumen pada beras berlabel jaminan varietas untuk Hipa 8, Ciherang dan Inpari 13. J. Penelit. Pertan. Tanam. Pangan 2016, 35, 173-180. (In Bahasa) [CrossRef]

(C) 2019 by the authors. Licensee MDPI, Basel, Switzerland. This article is an open access article distributed under the terms and conditions of the Creative Commons Attribution (CC BY) license (http://creativecommons.org/licenses/by/4.0/). 